\title{
DARK BORDERS
}




(C) 2011 Duke University Press

All rights reserved

Printed in the United States of America

on acid-free paper $\infty$

Designed by Jennifer Hill

Typeset in Arno Pro by Keystone Typesetting, Inc.

Library of Congress Cataloging-in-Publication Data

appear on the last printed page of this book.

Duke University Press gratefully acknowledges the support of the University of Maryland, which provided funds toward the production of this book. 